\title{
Occupational exposures and non-Hodgkin's lymphoma: Canadian
} case-control study

\author{
Chandima P Karunanayake1, Helen H McDuffieㄹ, James A Dosman¹, \\ John J Spinelli² and Punam Pahwa*1,3
}

Address: ${ }^{1}$ Canadian Centre for Health and Safety in Agriculture, University of Saskatchewan, Saskatoon, SK, Canada, ${ }^{2}$ Cancer Control Research, British Columbia Cancer Agency, British Columbia, Canada and ${ }^{3}$ Department of Community Health \& Epidemiology, University of Saskatchewan, Saskatoon, SK, Canada

Email: Chandima P Karunanayake-cpk646@mail.usask.ca; Helen H McDuffie-mcduffie@sask.usask.ca;

James A Dosman - james.dosman@usask.ca; John J Spinelli - jspinelli@bccrc.ca; Punam Pahwa* - pup165@mail.usask.ca

* Corresponding author

Published: 7 August 2008

Environmental Health 2008, 7:44 doi:10.1 186/1476-069X-7-44

This article is available from: http://www.ehjournal.net/content/7/I/44

(c) 2008 Karunanayake et al; licensee BioMed Central Ltd.

This is an Open Access article distributed under the terms of the Creative Commons Attribution License (http://creativecommons.org/licenses/by/2.0), which permits unrestricted use, distribution, and reproduction in any medium, provided the original work is properly cited.
Received: 17 March 2008

Accepted: 7 August 2008

\begin{abstract}
Background: The objective was to study the association between Non-Hodgkin's Lymphoma $(\mathrm{NHL})$ and occupational exposures related to long held occupations among males in six provinces of Canada.

Methods: A population based case-control study was conducted from 1991 to 1994. Males with newly diagnosed NHL (ICD-10) were stratified by province of residence and age group. A total of 513 incident cases and 1506 population based controls were included in the analysis. Conditional logistic regression was conducted to fit statistical models.

Results: Based on conditional logistic regression modeling, the following factors independently increased the risk of NHL: farmer and machinist as long held occupations; constant exposure to diesel exhaust fumes; constant exposure to ionizing radiation (radium); and personal history of another cancer. Men who had worked for 20 years or more as farmer and machinist were the most likely to develop NHL.

Conclusion: An increased risk of developing NHL is associated with the following: long held occupations of faer and machinist; exposure to diesel fumes; and exposure to ionizing radiation (radium). The risk of NHL increased with the duration of employment as a farmer or machinist.
\end{abstract}

\section{Background}

Non-Hodgkin's Lymphoma (NHL) is a cancer of the lymphatic system $[1,2]$. Even though NHL is a relatively rare disease, its incidence rates have been increasing worldwide for both men and women. The incidence rates in Canada, for both males and females were increased by about 50\% between 1978 and the late 1990s. After the lat- ter time, incidence rates have stabilized. Mortality rates of NHL have followed a similar pattern [3]. Age-standardized rates have increased faster among males than among females [1-5]. A number of factors, including inherited and acquired immunodeficiency states [6] as well as infectious, physical, and chemical agents have been associated with an increased risk for NHL $[6,7]$. 
Epidemiological studies have reported positive associations between NHL and certain occupations including those of farmers [8-16], pesticide applicators [12,17-20], drivers $[21,22]$, and managers $[23,24]$. Several studies have reported no association between development of NHL and the agricultural occupations (farmers, agricultural and forestry workers and pesticide applicators [2527]). Occupational exposures of a priori interest include pesticides [28-33], dusts (metal, wood, paper [8], etc), paints $[8,35]$, diesel exhaust fumes $[21,22,34,35]$, cleaning fluids [8], cutting oils [36], and solvents [37,38]. In this paper, we examined the association between NHL and (1) selected long term occupations, and (2) occupational exposures based on an individual's occupational history, and (3) duration of employment.

\section{Methods}

Details of the study design and methodology have been previously published [39-41]. Briefly, we conducted a six province Canadian population based case-control study of men with an incident first diagnosis of NHL between 1991 to 1994; control subjects were frequency matched by age \pm 2 years to be comparable with the age distribution of the entire case group (Soft Tissue Sarcoma (STS), Hodgkin's Disease (HD), NHL, and Multiple Myeloma (MM)) within each province of residence. The study had approximately three matched controls for each NHL case. Deceased subjects were ineligible as either cases or controls. All participating control subjects were used in the statistical analysis of each cancer site. Cases were identified from provincial cancer registries - except in Quebec where hospital records were used - and were coded using ICD-O $2^{\text {nd }}$ edition except Quebec which used ICD-O $1^{\text {st }}$ edition [42]. Malignant morphology codes 9591, 9642, 9670-9764, and 9823 were included. A reference pathologist reviewed the tumour tissue slides for $60 \%$ of the NHL cases, and confirmed NHL in all but $2 \%$ of cases. Cases not confirmed as NHL were eliminated. Control subjects were identified through provincial health insurance programs except in Ontario (telephone listing) and British Columbia (voter's lists), as generally described [39-41].

The study design consisted of two stages: Stage 1 was a self-administered postal questionnaire; and Stage 2 was a detailed pesticide exposure information collected via telephone interview. With permission, we modified a pesticide exposure questionnaire developed by Hoar et al. [43] to create the study questionnaire. The results in this manuscript are based on the Stage 1 postal questionnaire only.

The postal questionnaire captured demographic details, personal medical history, lifetime occupational history and specific occupational exposures of interest. Occupational information included a list of all full time jobs held by the respondent for at least one year. For each job held, we collected information on job titles, business organization - whether service or industry - and duration of employment. A list of occupational exposures that have been epidemiologically linked to NHL or to one of the other three types of cancers which we studied simultaneously was grouped into dusts, coal products, printing products, paints, metals, pesticides, radiation and miscellaneous. Additional details of exposure to agricultural chemicals in broad classes i.e. herbicides, fertilizers etc, were obtained. Job titles and each industry's coding were provided by Statistics Canada [44].

\section{Statistical analysis}

Data were entered into a custom designed SPSS-data entry program. Results were presented as frequencies for categorical variables; mean, standard deviation (SD) for continuous variables for cases and controls were presented separately. We obtained information about the duration of employment (measured in years) for each individual. The occupations were selected for analysis if the occupant worked in a particular occupation at least for one year and at least $2 \%$ of cases for that occupational category. Based on that information, we derived two new variables called ever held occupations and long held occupations. Occupations were defined as ever held occupation if respondents worked at least for one year in that occupation. Occupations were defined as long held occupation if respondents worked for 10 years or more in that occupation. Duration of employment is the total of number of years in each long held occupation. A bivariate analysis was conducted to determine the association between each explanatory variable and the NHL outcome. Based on this model, building procedure explanatory variables with $\mathrm{p}<$ 0.20 were selected for the multivariate model. Statistically significant $(\mathrm{p}=0.05)$ variables and important explanatory variables were considered for the final multivariate model adjusting for age and province of residence. Conditional logistic regression was used to compute adjusted odds ratios (OR) and 95\% confidence intervals (95\% CI).

\section{Ethics}

The letters of informed consent, questionnaires, and all other correspondence with study participants were approved by the relevant ethics agencies in each province. All of the information that could be used to identify study participants remained within each province of origin under the supervision of the provincial principal investigators.

\section{Results}

This study includes responses from 513 cases with NHL and 1506 control subjects. The mean age \pm standard deviation (SD) of cases was $57.7 \pm 14.0$ years and, of the controls, $54.1 \pm 16.0$ years. More cases $(\mathrm{n}=74,14.4 \%)$ than 
controls ( $\mathrm{n}=87,5.8 \%)$ had a personal history of cancer other than NHL $\left(\mathrm{OR}_{\mathrm{adj}}(95 \% \mathrm{CI}): 2.56\right.$ (1.81, 3.62)). There were no significant differences between NHL cases and controls with respect to their education level and to whether they ever lived or worked on a farm. Results are shown in Table 1.

Table 2 shows the distribution of ever held occupations and long held occupations during a lifetime stratified by case-control status. None of the ever held occupations were statistically significant. The long held occupations (10 years or more) as farmer and machinist showed a significant risk increase for NHL. The adjusted odds ratios $\left(\mathrm{OR}_{\mathrm{adj}}\right)$ and $95 \%$ confidence intervals $(95 \% \mathrm{CI})$ for a long held occupation during the lifetime as farmer and machinist were $1.54(1.05,2.27)$ and $2.21(1.02,4.79)$ respectively. Using four categories (no exposure, $<10$ years, 10-20 years, and > 20 years), further models with years in these industries were used to investigate whether or not there is a dose-response relationship between the long held occupation as a farmer and a machinist and NHL (Table 3). A dose-response relationship between duration of exposure as farmer and incidence of NHL was observed. Those who worked as a farmer for more than 20 years were 1.5 times more likely to be diagnosed with NHL than non-exposed subjects. Similarly, we observed a dose-response relationship between duration of exposure as a machinist and incidence of NHL. Those who worked as a machinist for more than 20 years were 2.3 times more likely to be diagnosed with NHL than non-exposed subjects (Table 3 ).

Of the 45 specific occupational exposures grouped into six classes (dusts, coal products, printing, paints, metals and miscellaneous), only exposure to diesel exhaust fumes showed an association with NHL (Table 4). Ever exposure to solvents and exposure to wood or paper dust were not associated with NHL. Ever exposure to ionizing radiation (radium) showed a significant association with the risk of NHL incidence (OR adj (95\% CI): 3.26 (1.38, 7.73)).

Table 5 shows the results of multivariate conditional logistic regression models for the long held jobs of farmer and machinist. The variables that remained statistically significantly associated with increased risk of NHL for long held job as a farmer were personal history of another cancer and exposure to ionizing radiation (radium). The variables for the long held job as a machinist associated with increased risk of NHL were personal history of another cancer, exposure to ionizing radiation (radium) and exposure to diesel. Duration of exposure for the long held jobs of farmer and machinist were borderline significant at 5\% level ( $p=0.08$ and $p=0.059)$, but there was evidence of an increase risk of NHL with longer duration of exposure.

\section{Discussion}

Our study investigated the association between NHL and several occupations and occupational exposures. The findings revealed that two long held occupations (10 years or more), farmer and machinist, were significantly associated with increased risk of developing NHL. One of the possible explanations is that farmers and drivers might be exposed to pesticides and engine exhaust and machinists might be exposed to solvents or engine exhaust at the work place. The increased risk of NHL for farmer and machinist seen in our study is consistent with the findings from other studies [8-16].

Table I: Characterization of study participants stratified by NHL case- control status: demographics and selected medical history

\begin{tabular}{|c|c|c|c|}
\hline & $\mathrm{NHL}(N=5 / 3)$ & Controls $(N=1506)$ & $\mathrm{OR}_{\text {adj }}^{\mathrm{b}}[\mathrm{PI}](95 \% \mathrm{Cl})$ \\
\hline \multicolumn{4}{|l|}{ Demographics } \\
\hline Mean age \pm SD (years) & $57.7 \pm 14.0$ & $54.1 \pm 16.0$ & \\
\hline \multicolumn{4}{|l|}{ Education Levela } \\
\hline University and Vocational & $28(6.6)$ & $96(5.5)$ & $1.23(0.81,1.88)$ \\
\hline University & $94(18.5)$ & $310(20.8)$ & $1.08(0.68,1.70)$ \\
\hline Vocational & $111(21.9)$ & $358(24.1)$ & $1.06(0.67,1.70)$ \\
\hline Elementary/High school & $274(54.0)$ & $723(48.6)$ & 1.00 \\
\hline \multicolumn{4}{|l|}{ Ever lived/worked on a farm } \\
\hline Yes n (\%) & $235(45.8)$ & $673(44.7)$ & $1.02(0.82,1.27)$ \\
\hline No n (\%) & $278(54.2)$ & $833(55.3)$ & 1.00 \\
\hline \multicolumn{4}{|l|}{ Medical History } \\
\hline \multicolumn{4}{|l|}{ Previous diagnosis of Cancer } \\
\hline Yes n (\%) & $74(14.4)$ & $87(5.8)$ & $2.56(1.81,3.62)^{c}$ \\
\hline No n (\%) & $439(85.6)$ & $1419(94.2)$ & 1.00 \\
\hline
\end{tabular}

a 25 missing

b Adjusted for age (5 year groups) and province

c Statistically significant results are bold. 
Table 2: Adjusted odds ratio (OR) and $95 \%$ confidence interval $(95 \% \mathrm{Cl})$ for different occupations (job titles).

\begin{tabular}{|c|c|c|c|}
\hline Job Title (code\#) & $\begin{array}{c}\mathrm{NHL} \text { cases } \\
\mathrm{n}(\%)\end{array}$ & $\begin{array}{c}\text { Controls } \\
\text { n (\%) }\end{array}$ & $\mathrm{OR}_{\mathrm{adj}}$ a $(95 \% \mathrm{Cl})$ \\
\hline \multicolumn{4}{|l|}{ Ever held Occupations } \\
\hline Accountant (I) & $30(5.8)$ & $8 \mathrm{I}(5.4)$ & $1.21(0.77,1.89)$ \\
\hline Administrator (2) & II (2.I) & $52(3.4)$ & $0.58(0.30,1.15)$ \\
\hline Carpenter (I2) & $21(4.1)$ & $55(3.6)$ & $1.06(0.63,1.79)$ \\
\hline Clerk (I7) & $14(2.7)$ & $92(6.1)$ & $0.44(0.24,0.79)$ \\
\hline Constructor (19) & $14(2.7)$ & $78(5.2)$ & $0.5 \mathrm{I}(0.28,0.93)$ \\
\hline Driver (25) & $55(10.7)$ & $133(8.8)$ & $1.29(0.91,1.82)$ \\
\hline Electrician (26) & $16(3.1)$ & $47(3.1)$ & $0.99(0.54,1.78)$ \\
\hline Engineer (27) & $13(2.5)$ & $68(4.5)$ & $0.54(0.29,1.02)$ \\
\hline Factory worker (29) & $13(2.5)$ & $46(3.0)$ & $1.14(0.59,2.17)$ \\
\hline Foreman (30) & II (2.I) & $39(2.6)$ & $0.64(0.32,1.28)$ \\
\hline Farmer $(31,33,89)$ & $86(16.7)$ & $230(15.3)$ & $1.14(0.85,1.54)$ \\
\hline Armed forces (138) & $28(5.5)$ & $92(6.1)$ & $0.76(0.48,1.18)$ \\
\hline Janitor (4I) & $14(2.7)$ & $40(2.7)$ & I.07 $(0.57,2.02)$ \\
\hline Labourer (44) & $31(6.0)$ & $99(6.6)$ & $0.86(0.56,1.33)$ \\
\hline Lumberman (46) & $17(3.3)$ & $38(2.5)$ & $1.12(0.61,2.03)$ \\
\hline Machinist (47) & $22(4.3)$ & $49(3.2)$ & $1.4 \mid(0.83,2.40)$ \\
\hline Manager (48) & $63(12.3)$ & $183(12.1)$ & $0.97(0.70,1.33)$ \\
\hline Mechanic (49) & $26(5.1)$ & $88(5.8)$ & $0.83(0.52, \mid .31)$ \\
\hline Salesman (73) & $44(8.6)$ & $127(8.4)$ & $1.06(0.73,1.53)$ \\
\hline School Teacher (74) & $31(6.0)$ & $88(5.8)$ & $0.96(0.62,1.48)$ \\
\hline Welder (86) & $13(2.5)$ & $33(2.2)$ & $1.25(0.64,2.44)$ \\
\hline Office worker (97) & $17(3.3)$ & $68(4.5)$ & $0.70(0.40,1.22)$ \\
\hline Equipment hander (I34) & $14(2.7)$ & $37(2.5)$ & $1.34(0.70,2.56)$ \\
\hline \multicolumn{4}{|l|}{ Long held Occupations } \\
\hline Accountant (I) & $20(3.9)$ & $4 \mathrm{I}(2.7)$ & $1.39(0.79,2.42)$ \\
\hline Driver (25) & $27(5.3)$ & $48(3.2)$ & I.45 $(0.88,2.37)$ \\
\hline Farmer $(31,33,89)$ & $50(9.8)$ & $106(7.0)$ & $1.54(1.05,2.27)^{c}$ \\
\hline Machinist (47) & $12(2.3)$ & $16(1.1)$ & $2.21(1.02,4.79)^{c}$ \\
\hline Manager (48) & $31(6.0)$ & $96(6.4)$ & $0.86(0.56,1.32)$ \\
\hline Mechanic (49) & $15(2.9)$ & $49(2.2)$ & $1.00(0.99,1.02)$ \\
\hline
\end{tabular}

\# Statistics Canada. Standard occupational classification. Ottawa: Minister of Supply and Services, 1980.

a All odds ratios were adjusted for age and province of residence.

c Statistically significant results are bold.

Table 3: Duration of exposure as a farmer and machinist and risk of NHL

\begin{tabular}{|c|c|c|c|}
\hline Duration (in years) & $\begin{array}{c}\mathrm{NHL}(\mathrm{N}=5 / 3) \\
\mathrm{n}(\%)\end{array}$ & $\begin{array}{c}\text { Control }(N=1506) \\
n(\%)\end{array}$ & OR $(95 \% \mathrm{Cl})^{\mathrm{a}}$ \\
\hline \multicolumn{4}{|l|}{ Job Title: Farmer } \\
\hline No exposure & $427(83.2)$ & $1276(84.7)$ & 1.00 \\
\hline$<10$ years & $36(7.0)$ & $124(8.2)$ & $0.84(0.5 \mathrm{I}, \mathrm{I} .4 \mathrm{I})$ \\
\hline $10-20$ years & $7(1.4)$ & $23(1.5)$ & $1.40(0.57,3.43)$ \\
\hline$>20$ years & $43(8.4)$ & $83(5.5)$ & $1.55(1.02,2.36)^{c}$ \\
\hline \multicolumn{4}{|l|}{ Job Title: Machinist } \\
\hline No exposure & 491 (95.7) & 1457 (96.7) & 1.00 \\
\hline$<10$ years & $10(1.9)$ & $33(2.2)$ & $0.75(0.30,1.88)$ \\
\hline $10-20$ years & $2(0.4)$ & $4(0.3)$ & $1.77(0.31,10.22)$ \\
\hline$>20$ years & $10(1.9)$ & $12(0.8)$ & $2.33(1.00,5.52)^{c}$ \\
\hline
\end{tabular}

a all odds ratios were adjusted for age and province of residence.

c Statistically significant results are bold. 
Table 4: Adjusted odds ratio (OR) and $95 \%$ confidence interval $(95 \% \mathrm{Cl})$ for different occupational exposures.

\begin{tabular}{|c|c|c|c|c|c|}
\hline \multirow[b]{2}{*}{ Exposure } & \multicolumn{2}{|c|}{$\mathrm{NHL}(\mathrm{N}=5 / 3)$} & \multicolumn{2}{|c|}{ Control $(N=1506)$} & \multirow[b]{2}{*}{$\mathrm{OR}_{\mathrm{adj}}(95 \% \mathrm{Cl})^{\mathrm{a}}$} \\
\hline & $n^{b}$ & $\%$ & $\mathrm{n}^{\mathrm{b}}$ & $\%$ & \\
\hline \multicolumn{6}{|l|}{ Dusts } \\
\hline Cement dust & 134 & 26.1 & 432 & 28.7 & $0.93(0.73,1.18)$ \\
\hline Fiberglass dust & 102 & 19.9 & 319 & 21.2 & $1.02(0.78,1.33)$ \\
\hline Coal dust & 63 & 12.3 & 149 & 9.9 & $1.19(0.86,1.66)$ \\
\hline Soil/field dust & 142 & 27.7 & 375 & 24.9 & $1.26(0.99,1.61)$ \\
\hline Whey dust & 12 & 2.3 & 38 & 2.5 & $0.89(0.45,1.77)$ \\
\hline Paper dust & 68 & 13.3 & 180 & 11.9 & $1.22(0.89,1.67)$ \\
\hline Wood dust & 143 & 27.9 & 445 & 29.5 & $0.95(0.75,1.20)$ \\
\hline Coke dust & 10 & 1.9 & 58 & 3.8 & $0.53(0.26,1.06)$ \\
\hline Stone dust & 55 & 10.7 & 173 & 11.5 & $0.99(0.7 \mathrm{I}, \mathrm{I} .40)$ \\
\hline Grain Dust & 117 & 22.8 & 347 & 23.0 & $0.99(0.76,1.29)$ \\
\hline Sand & 90 & 17.5 & 303 & 20.1 & $0.89(0.67,1.16)$ \\
\hline Cardboard dust & 50 & 9.7 & 170 & 11.3 & $1.01(0.71,1.44)$ \\
\hline Metal dust & 120 & 23.4 & 368 & 24.4 & $1.06(0.82,1.36)$ \\
\hline \multicolumn{6}{|l|}{ Coal Products } \\
\hline Pitch & 17 & 3.3 & 38 & 2.5 & $1.24(0.68,2.25)$ \\
\hline Asphalt & 46 & 8.9 & 142 & 9.4 & $0.96(0.67,1.38)$ \\
\hline Crude petroleum & 30 & 5.8 & 84 & 5.6 & $1.00(0.64,1.57)$ \\
\hline Tar/tar products & 53 & 10.3 & 143 & 9.5 & $1.20(0.84,1.69$ \\
\hline \multicolumn{6}{|l|}{ Printing } \\
\hline Printing inks & 35 & 6.8 & 134 & 8.9 & $0.90(0.60,1.36)$ \\
\hline Printing fluid & 28 & 5.5 & 96 & 6.4 & $0.93(0.59,1.47)$ \\
\hline \multicolumn{6}{|l|}{ Paints } \\
\hline Paints, dyes & 148 & 28.8 & 442 & 29.3 & $1.06(0.84,1.33)$ \\
\hline \multicolumn{6}{|l|}{ Metals } \\
\hline Arsenic & 13 & 2.5 & 28 & 1.9 & I. $45(0.72,2.93)$ \\
\hline Nickel & 29 & 5.6 & 85 & 5.6 & I.II (0.7I, I.74) \\
\hline Cadmium & 20 & 3.9 & 55 & 3.6 & $1.07(0.62,1.84)$ \\
\hline Zinc & 38 & 7.4 & 103 & 6.8 & $1.12(0.75,1.67)$ \\
\hline Mercury & 20 & 3.9 & 63 & 4.2 & $0.84(0.49,1.43)$ \\
\hline Chromium & 24 & 4.7 & 58 & 3.8 & $1.33(0.79,2.22)$ \\
\hline Iron & 40 & 7.8 & 100 & 6.6 & I.I8 (0.79, I.77) \\
\hline Lead & 65 & 12.7 & 182 & 12.1 & $1.03(0.75,1.42)$ \\
\hline Aluminum & 71 & 13.8 & 220 & 14.6 & $1.03(0.76,1.40)$ \\
\hline \multicolumn{6}{|l|}{ Miscellaneous } \\
\hline Asbestos & 76 & 14.8 & 237 & 15.7 & $0.91(0.68,1.21)$ \\
\hline Used motor oil & 117 & 22.8 & 400 & 26.6 & $0.89(0.69,1.15)$ \\
\hline Diesel exhaust fumes & 183 & 35.7 & 464 & 30.8 & $1.33(1.06,1.67)^{c}$ \\
\hline Cutting oils & 74 & 14.4 & 277 & 18.4 & $0.81(0.60,1.08)$ \\
\hline Cleaning fluids & 124 & 24.2 & 419 & 27.8 & $0.93(0.72,1.19)$ \\
\hline Preservatives & 9 & 1.7 & 21 & 1.4 & I.II $(0.49,2.50)$ \\
\hline Chlorine & 68 & 13.3 & 202 & 13.4 & $1.05(0.77,1.43)$ \\
\hline Hair permanent solutions & 11 & 2.1 & 33 & 2.2 & $0.99(0.48,2.04)$ \\
\hline Sour gas & 24 & 4.7 & 92 & 6.1 & $0.69(0.42,1.12)$ \\
\hline Wood smoke & 121 & 23.6 & 371 & 24.6 & $0.95(0.75,1.22)$ \\
\hline Lubricants & 152 & 29.6 & 477 & 31.7 & $0.99(0.78,1.25)$ \\
\hline Solvents & 167 & 32.5 & 516 & 34.3 & $1.01(0.80,1.28)$ \\
\hline Ether & 51 & 9.9 & 170 & 11.3 & $0.88(0.62,1.25)$ \\
\hline Mouldy grain/forage & 61 & 11.9 & 176 & 11.7 & $1.09(0.78,1.53)$ \\
\hline Hair dyes & 15 & 2.9 & 33 & 2.2 & $1.33(0.69,2.52)$ \\
\hline Cyanide & 10 & 1.9 & 36 & 2.4 & $0.79(0.38,1.63)$ \\
\hline
\end{tabular}


Table 4: Adjusted odds ratio (OR) and $95 \%$ confidence interval $(95 \% \mathrm{Cl})$ for different occupational exposures. (Continued)

\begin{tabular}{lccccc}
\hline \hline Non-ionizing radiation & & & & & \\
$\quad$ Ultra Violet Light & 44 & 8.6 & 151 & 10.0 & $1.06(0.73,1.55)$ \\
$\quad$ Horticultural Grow lights & 12 & 2.3 & 39 & 2.59 & $0.91(0.46,1.79)$ \\
$\quad$ Unshielded microwaves & 3 & 0.6 & 25 & 1.7 & $0.39(0.11,1.32)$ \\
\hline Ionizing radiation & & & & \\
$\quad$ Radium & 12 & 2.34 & 12 & 0.80 & $\mathbf{3 . 2 6 ( 1 . 3 8 , 7 . 7 3 ) ^ { c }}$ \\
$\quad$ Uranium & 12 & 2.34 & 18 & 1.20 & $2.10(0.97,4.56)$ \\
\hline
\end{tabular}

a all odds ratios were adjusted for age and province of residence.

$\mathrm{b}_{\mathrm{n}}$ and $\%$ are given for the "yes" responses.

c Statistically significant results are bold.

Pesticides including herbicides and insecticides have been associated with Non-Hodgkin's Lymphoma in studies of farmers, agricultural related workers, other pesticide applicators, manufacturing workers and other exposed populations $[39,45]$. Grain handlers exposed to pesticides, grain dusts, and organic solvents were shown a fivefold risk of NHL [46]. Our study confirms that those who held the long held job title as a farmer (farmer, farm labourer and farm managers) had 1.5 times higher risk of being diagnosed with NHL than those who held a job title from the category of non-farmer.

Our results confirm previously reported associations of NHL and a personal history of cancer $[47,48]$. Occupational exposure to dust (wood, paper, metal etc.), coal products, paints, metal, and printing are unlikely to increase the risk of NHL, as is evident from our analysis. In contrast, Kawachi et al [49] found a significant association between working with wood and NHL. In addition, Kogevinas et al [50] found an increased risk of Lymphomas in pulp and paper workers. Ever exposure to diesel exhaust fumes is likely to increase the risk of NHL, as is evident from our analysis. Our finding is agreement for diesel exhaust fumes with Baris et al [21] and Maizlish et al [34].
The mechanism of cancer induction by radiation suggested in our study is not clear. The most widely accepted hypothesis is that some of the ionizing events, which occur when radiation is absorbed in tissue, produce a change in the genes or chromosomes of one or more cells [51]. A case-referent study conducted to investigate the possible association between occupation and occupational exposures and risk of hematological malignancies showed that exposure to asbestos, hydrocarbons, fertilizer, radiation, pesticides and mineral oils were highly associated with hematological malignancies [10]. Another matched case-control study in the nuclear industry [52] found no significant excess of NHL at any radiation exposure level. Archer [51] stated that uranium mill workers appeared to have excess Lymphomas. In our study, any form of radiation exposure at work was considered. Exposure to ionizing radiation (radium) is significantly associated with increase risk of $\mathrm{NHL}$, which suggests equivocal evidence of an association with NHL presented by Ron [53].

There are many potential sources of non-ionizing radiation to workers. One of them is ultraviolet (UV) radiation. There is suggestive evidence that exposure to ultraviolet (UV) light, an established cause of immune suppression, may increase the risk of NHL [54-57]. The most recent epi-

Table 5: Multivariate models of the important covariates associated with NHL for long held occupations.

\begin{tabular}{|c|c|c|}
\hline \multirow[t]{2}{*}{ Variable } & Farmer & Machinist \\
\hline & OR $(95 \% \mathrm{Cl})^{\mathrm{a}}$ & OR $(95 \% \mathrm{Cl})^{\mathrm{a}}$ \\
\hline Personal history of another cancer (yes) & $2.60(1.83,3.69)^{c}$ & $2.57(1.82,3.65)^{c}$ \\
\hline Ever exposed to ionizing radiation (radium) (yes) & $3.41(1.44,8.11)^{c}$ & $3.21(1.34,7.67)^{c}$ \\
\hline Ever exposed to diesel (yes) & $1.23(0.97,1.56)$ & $1.28(1.02,1.61)^{c}$ \\
\hline \multicolumn{3}{|l|}{ Duration (reference to no exposure) } \\
\hline$<10$ years & $0.77(0.45,1.30)$ & $0.73(0.29,1.86)$ \\
\hline $10-20$ years & $1.34(0.54,3.34)$ & $1.87(0.33,10.57)$ \\
\hline$>20$ years & $1.47(0.95,2.29)$ & $2.34(0.97,5.68)$ \\
\hline
\end{tabular}

a all odds ratios were adjusted for age and province of residence.

c Statistically significant at $5 \%$ level results are bold. 
demiologic literature suggests that there is no association or protective effect between exposure to sunlight and NHL [58-63]. Our study did not find any association between exposure to ultraviolet (UV) light with NHL.

Solvents have been associated with NHL in a number of studies [64-66], including studies of rubber workers [67], aircraft maintenance workers [68], and dry cleaners [69]. In particular, benzene exposure is common in above mention occupations and this may be due to its effects on the immune system [66]. Other occupations which might involve exposure to solvents or related chemicals and which are reported as being at increased risk of NHL include those of highway workers [34], petroleum refinery employees [70-72], styrene workers [73], chemists $[74,75]$, and chemical manufacturers [76,77]. We could not find any association between NHL and exposure to solvents, cleaning fluids, or preservatives.

A major strength of this study is the large number of cases and controls from residents of six Canadian provinces. Questions were designed to obtain a complete occupational history and extensive list of potential occupational exposures. A reference pathologist validated $84 \%$ of the NHL tumours.

There are, however, several limitations in this study. One of the limitations is the potential for recall bias and misclassification of pesticide exposures. Also, occupational exposures in this study were self-reported and this might also bias results. Due to budget constraints, the study was restricted to males. The response rates of $67.1 \%$ for cases and $48 \%$ for controls represent another potential limitation that could create misleading conclusions if the nonrespondents differ significantly from the respondents with respect to the variables under investigation. We compared non-respondents to respondents using postal codes as an indicator of rural residence and did not find a rural bias among respondents. The most common reasons for not participating were death, change of address, and refusal for both cases and controls. Another limitation was the possibility of false-positive findings given the large number of jobs and exposures assessed.

\section{Conclusion}

Our results support previous findings of an association between NHL and specific job titles and occupational exposures. In our analysis, NHL was associated with personal history of cancer, exposure to diesel exhaust fumes, exposure to ionizing radiation (radium) and long held occupations such as farmer and machinist. Also, we have supportive evidence of increased risk of NHL with longer durations of exposure.

\section{Abbreviations}

NHL: Non-Hodgkin's Lymphoma; ICD: International Classification of Diseases; STS: Soft Tissue Sarcoma; HD: Hodgkin's Disease; MM: Multiple Myeloma.

\section{Competing interests}

The authors declare that they have no competing interests.

\section{Authors' contributions}

CPK analyzed data and prepared the manuscript. HHM designed, coordinated the study and collect the data. JAD participated in study design, coordination, data collection and manuscript preparation. JJS participated in the design of the study and data collection. PP designed and coordinated the study as well as collected and prepared the manuscript.

\section{Acknowledgements}

Special thanks go to the collaborators Drs. G. Theriault, J. McLaughlin, D. Robson, S. Fincham, L. Skinnider, D. White, T. To and Late N.W. Choi. Also, the authors are indebted to the following members of the Advisory Committee: Drs. G.B. Hill, A. Blair, L. Burmeister, H. Morrison, R. Gallagher, and D. White. We owe a debt of gratitude to the provincial coordinators across Canada and data managers for their meticulous attention to detail: T. Switzer, M. Gantefor, J. Welyklowa, J. Ediger, I. Fan, M. Ferron, E. Houle, S. de Freitas, K. Baerg, L. Lockinger, E. Hagel, P. Wang, G. Dequiang, J. Hu. We thank Drs. G. Theriault and N. Choi for supervising the collection of data in Quebec and Manitoba respectively; and to Dr. L. Skinnider for reviewing the pathological specimens. The study participants gave freely of their time and shared personal details with us and we sincerely thank each of them. Written consent for publication was obtained from the participants. This work was funded by Health Canada National Health Research Programs Directorate Grant 6608-1258, the British Columbia Health Research Foundation and Institute of Agricultural, Rural and Environmental Health, University of Saskatchewan.

\section{References}

I. Evans LS, Hancock BW: Non-Hodgkin lymphoma. Lancet 2003, 362:139-146.

2. National Cancer Institute: "What you need to know about NonHodgkin's Lymphoma". In NIH Publication; No. 05-1567 Bethesda, Maryland; 2005.

3. Canadian Cancer Society/National Cancer Institute of Canada: Canadian Cancer Statistics 2007. Toronto, Canada 2007.

4. Fisher RI, Mauch PM, Harris NL, Friedberg JW: Non-Hodgkin's lymphomas. In Cancer: Principles and Practice of Oncology 7th edition. Edited by: DeVita VT, Hellman S, Rosenberg SA. Philadelphia: Lippincott Williams and Williams; 2005:1957-1997.

5. American Cancer Society: Cancer Facts and Figures 2005. [http://www.cancer.org/downloads/STT/ CAFF2005f4PWSecured.pdf].

6. Ziegler JL, Beckstead JA, Volberdina PA, Abrams DJ, Levine AM, Lukes RJ: Non-Hodgkin's lymphoma in $\mathbf{9 0}$ homosexual men: relationship to generalized lymphadenopathy and acquired immunodeficiency syndrome. N Engl J Med I 984, 3 I I:565-70.

7. Vineis P, D'Amore F, Working Group on the Epidemiology of Hematolymphopoietic Malignancies in Italy: The Role of Occupational Exposure and Immunodeficiency in B-Cell Malignancies. Epidemiology 1992, 3:266-270.

8. Blair A, Linos A, Stewart PA, Burmeister LF, Glbson R, Everett G, Schuman L, Cantor KP: Evaluation of Risks for Non-Hodgkin's Lymphoma by Occupation and Industry Exposures from a Case-Control Study. Am J Ind Med 1993, 23:30I-3I2.

9. Vecchia CL, Negri E, D'Avanzo B, Franceschi S: Occupation and lymphoid neoplasms. Br J Cancer 1989, 60:385-388. 
10. Pasqualetti P, Casale R, Colantonio D, Collacciani A: Occupational Risk for Hematological Maligancies. Am J Hematology 1991, 38:147-|49.

II. Amadori D, Nanni O, Falcini F, Saragoni A, Tison V, Callea A, Scarpi E, Ricci M, Riva N, Buiatti E: Chronic lymphocytic leukaemias and Non-Hodgkin's lymphomas by histological type in farming-animal breeding workers: a population case-control study based on job titles. Occup Environ Med I 995, 52:374-379.

12. Woods JS, Polissar L, Severson RK, Heuser LS, Kulander BG: Soft Tissue Sarcoma and Non-Hodgkin's Lymphoma in Relation to Phenoxyherbicide and Chlorinated Phenol Exposure in Western Washington. I Natl Cancer Inst 1987, 78:899-9I0.

13. Zheng T, Blair A, Zhang Y, Weisenburger DD, Zahm SH: Occupation and Risk of Non-Hodgkin's Lymphoma and Chronic Lymphocytic Leukemia. J Occup Environ Med 2002, 44:469-474.

14. Persson B: Occupational Exposure and Malignant Lymphoma. Int J Occu Med and Env Health 1996, 9:309-321.

I5. Cantor KP, Blair A, Everett G, Gibson R, Burmeister LF, Brown LM, Schuman L, Dick FR: Pesticides and Other Agricultural Risk factors for Non-Hodgkin's Lymphoma among Men in lowa and Minnesota. Cancer Res 1992, 52:2447-2455.

16. Pearce N, Bethwaite P: Increasing Incidence of Non-Hodgkin's Lymphoma: Occupational and Environmental Factors. Cancer Res 1992, 52(Suppl 19):5496s-5500s.

17. Morrison HI, Semenciw WK, Mao Y, Wigle D: Herbicides and Cancer. I Natl Cancer Inst 1992, 84:|866-I874.

18. Alavanja MCR, Blair A, Merkle S, Teske J, Eaton B, Reed B: Mortality among Forest and soil Conservations. Arch Environ Health 1989. 44:94- 101 .

19. Kross BC, Burmeister LF, Ogilvie LK, Fuortes LJ, Fu CM: Proportionate Mortality Study of Golf Course Superintendents. Am J Ind Med 1996, 29:501-506.

20. Cantor KP, Blair A, Brown LM, Burmeister LF, Everett G: Pesticides and other Agricultural risk factors for Non-Hodgkin's Lymphoma among Men in lowa and Minnesota. Cancer Res 1993, 53:2421

21. Baris D, Garrity TJ, Telles JL, Heineman EF, Olshan A, Zahm SH: Cohort Mortality Study of Philadelphia Firefighters. Am J Ind Med 200I, 39:463-476.

22. Balarajan R: Malignant Lymphomas in Road Transport Workers. J Epidemiol Community Health 1983, 37(4):279-280.

23. Costantini AS, Miligi L, Kriebel D, Ramazzotti V, Rodella S, Scarpi E Stagnaro E, Tumino R, Fontana A, Masal G, Vigano C, Vindigni D, Crosignani P, Benrenuti A, Vineis P: A multicenter Case-Control study in Italy on Hematolymphopoietic Neoplasms and Occupation. Epidemiology 2001, 2 1:78-87.

24. Lagorio S, Forastiere F, lavarone I, Rapitie E, Vanacore N, Perucci CA Carere A: Mortality of Filling Station Attendants. Scand J Work Environ Health 1994, 20:331-338.

25. Hardell L, Eriksson M, Degerman A: Exposure to Phenoxyacetic Acids, Chlorophenols, or Organic Solvents in Relation to Histopathology. Stage and Anatomical Localization of NonHodgkin's Lymphoma. Cancer Res 1994, 54:2386-2389.

26. Wiklund K, Lindefors BM, Holm LE: Risk of malignant lymphoma in Swedish agricultural and forestry workers. $\mathrm{Br} J$ Ind Med 1988, 45:19-24.

27. Wiklund K, Dich J, Holm LE: Risk of Soft Tissure Sarcoma Hodgkin's Disease and Non-Hodgkin Lympoma among Swedish Licensed Pesticide Applicators. Chemosphere: Science for Environmental Technology 1989, 18:395-400.

28. Pollán M, López-Abente G, Moreno C, Vergara A, Aragonés N, Ruiz M, Ardanaz E, Moreo P: Rising Incidence of Non-Hodgkin's Lymphoma in Spain: Analysis of period of Diagnosis and Cohort Effects. Cancer Epidemiol Biomarkers Prev 1998, 7(7):62I-625

29. Hill G, Fincham S, McDuffie HH, To T, Dosman JA: Relationship between pesticide use and the incidence of soft tissue sarcoma, Hodgkin's disease, Non-Hodgkin's lymphoma and multiple myeloma. Chronic Diseases in Canada 1988, 9:1 I3-1 I6.

30. Hertzman C, Teschke K, Ostry A, Hershler R, Dimich-Ward H, Kelly S, Spinelli J], Gallagher RP, McBride M, Marion SA: Mortality and Cancer Incidence among Sawmill Workers Exposed to Chlorophenate Wood Preservatives. Am J Public Health 1997 87:7|-79.

31. O'Brien TR, Decouflé , Boyle CA: Non-Hodgkin's Lymphoma in a Cohort Vietnam Veterans. Am J Public Health I991, 8 I:758-760.
32. Persson B, Fredriksson M: Some risk factors for Non-Hodgkin's Lymphoma. Int J Occu Med Env Health 1999, I 2: | 35- I42.

33. Zahm SH, Weisenburger DD, Babbitt PA, Saal RC, Vaught JB, Cantor KP, Blair A: A case-control study of Non-Hodgkin's Lymphoma and the Herbicide 2,4- Dichlorophenoxyacetic Acid (2,4-D) in Eastern Nebraska. Epidemiology I990, I:349-356.

34. Maizlish N, Beaumont J, Singleton J: Mortality among California Highway Workers. Am J Ind Med 1998, I3:363-379.

35. Blair A, Linos A, Stewart PA, Burmeister LF, Gibson R, Everett G Schuman L, Cantor KP: Comments on Occupational and Environmental Factors in the origin of Non-Hodgkin's Lymphoma. Cancer Res 1992, 52(Suppl 19):5501s-5502s.

36. Mao Y, Hu J, Ugnat AM, White K, for the Canadian Cancer Registries Epidemiology Research Group: Non-Hodgkin's Lymphoma and Occupational exposure to chemicals in Canada. Ann Oncol 2000, I I (SuppI I):S69-S73.

37. Lynge E, Anttila A, Hemminki K: Organic solvents and cancer. Cancer Cause Control 1997, 8:406-4I9.

38. Tatham L, Tolbert P, Kjeldberg C: Occupational Risk Factors for Subgroups of Non-Hodgkin's Lymphoma. Epidemiology 1997, 8:55I-558.

39. McDuffie HH, Pahwa P, McLaughlim JR, Spinelli JJ, Fincham S, Dosman JA, Robson D, Skinnider LF, Choi NW: Non-Hodgkin's Lymphoma and specific pesticide exposure in men: Cross-Canada study of pesticides and Health. Cancer Epidem Biomar 200I, I O(I I): II55-II63.

40. Pahwa P, McDuffie HH, Dosman JA, McLaughlin JR, Spinelli JJ, Robson D, Fincham S: Hodgkin's Lymphoma, Multiple Myeloma, Soft Tissue Sarcomas, Insect Repellents and Phenoxyherbicides. J Occup Environ Med 2006, 48:264-274.

4I. McDuffie HH, Pahwa P, Robson D, Dosman JA, Fincham S, Spinelli J], McLaughlin JR: Insect repellents, phenoxyherbicide exposure, and non-Hodgkin's Iymphoma. J Occup Environ Med 2005, 47:806-816.

42. ICD-10: International Statistical Classification of Diseases and Related Health Problems. I $0^{\text {th }}$ Revision. Volume I-3. World Health Organization, Geneva, Switzerland

43. Hoar SK, Blair A, Holmes F, Boysen CD, Robel RJ, Hoover R, Fraumeni JF: Agricultural herbicide use and risk of lymphoma and soft tissue sarcoma. J Am Med Assn 1986, 256: | | 4|- | | 47.

44. Minister of supply and services: Statistics Canada standard occupational classification. Ottawa 1980.

45. Zahm SH, Blair A: Pesticides and non-Hodgkin's lymphoma. Cancer Res 1992, 52(Suppl 19):5485s-5488s.

46. Alavanja MC, Blair A, Masters MN: Cancer mortality in the U.S. flour industry. J Natl Cancer Inst 1990, 82:840-848.

47. Cerhan JR, Wallace RB, Folsom AR, Potter JD, Sellers TA, Zheng W, Lutz CT: Medical history risk factors for non-Hodgkin's lymphoma in older women. J Natl Cancer Inst 1997, 89(4):3 I4-3 I8.

48. Berstein R, Ross RK: Prior medication use and health history as risk factors for non-Hodgkin's lymphoma: preliminary results from a case-control study in Los Angeles County. Cancer Res 1992, 52(Suppl 19):5510s-55I5s.

49. Kawachi I, Pearce NE, Fraser J: A New Zealand Cancer Registrybased study of cancer in wood workers. Cancer (Phila.) I 989, 64:2609-2613.

50. Kogevinas M, Boffetta P, Saracci R: Review of carcinogenic risks in the pulp and paper industry. Proceedings of the Dioxin' 90 International Conference: September 1990; Bayreuth, Germany

5I. Archer VE: Occupational Exposure to Radiation as a Cancer Hazard. Cancer 1977, 39:1802-1806.

52. Kinlen LJ, Clarke K, Balkwill A: Paternal preconceptional radiation exposure in the nuclear industry and leukaemia and non-Hodgkin's lymphoma in young people in Scotland. BM 1993, 306(6886): I I53-II58.

53. Ron $E$ : lonizing radiation and cancer risk: evidence from epidemiology. Pediatr Radiol 2002, 32:232-237.

54. Kinlen ML: Immunosuppressive therapy and acquired immunological disorders. Cancer Res 1992, 52(Suppl 19):5474s-5476s.

55. Kripke ML: Effects of UV Radiation on Tumor Immunity. J Natl Cancer Inst 1990, 82: I392-1396.

56. Karipidis KK, Benke G, Sim MR, Kauppinen T, Kricker A, Hughes AM, Grulich AE, Vajdic CM, Kaldor J, Armstrong B, Fritschi L: Occupational exposure to ionizing and non-ionizing radiation and risk of non-Hodgkin Iymphoma. Int Arch Occup Environ Health 2007, 80:663-670. 
57. Zhang $Y$, Holford TR, Leaderer B, Boyle $P$, Zhu $Y$, Wang R, Zou K, Zhang B, Wise JP, Qin Q, Kilfoy B, Han J, Zheng T: Ultraviolet radiation exposure and risk of non-Hodgkin's lymphoma. Am J Epidemio 2007, 165:1255-1264.

58. Freedman DM, Zahm SH, Dosemeci M: Residentional and occupational exposure to sunlight and mortality from non-Hodgkin's lymphoma: composite (threefold) case-control study. [http://www.bmj.com/cgi/content/full/3/4/7092//45I].

59. Adami J, Gridley G, Nyren O, Dosemeci M, Linet M, Glimelius B Sunlight and Non-Hodgkin's Lymphoma: A PopulationBased Cohort Study in Sweden. Int J Cancer 1999, 80:64I-645.

60. Purdue MP, Hartge P, Davis S, Cerhan JR, Colt JS, Cozen W, Severson RK, Li Y, Chanock SJ, Rothman N, Wang SS: Sun exposure, vitamin $D$ receptor gene polymorphisms and risk of non-Hodgkin lymphoma. Cancer Cause Control 2007, I 8:989-999.

61. Hartge P, Lim U, Freedman DM, Colt JS, Joanne S, Cerhan JR, Cozen W, Severson RK, Davis S: Ultraviolet radiation, dietary vitamin $D$, and risk of non-Hodgkin lymphoma(United States). Cancer Cause Control 2006, 17:1045-1052.

62. Tavani A, Bosetti C, Franceschi S, Talamini R, Negri E, La Vecchia C: Occupational exposure to ultraviolet radiation and risk of non-Hodgkin lymphoma. Eur J Cancer Prev 2006, I 5:453-457.

63. Kricker A, Armstrong BK, Hughes AM, Goumas C, Smedby KE, Zheng T, Spinelli JJ, De Sanjose S, Hartge P, Melbye M, Willett EV, Becker N, Chiu BC, Cerhan JR, Maynadie M, Staines A, Cocco A, Boffeta P, Interlymph Consortium: Personal sun exposure and risk of non Hodgkin lymphoma: a pooled analysis from the Interlymph Consortium. Int J Cancer 2008, I 22: 144-54.

64. Persson B, Dahlander AM, Fredriksson M, Brage HN, Ohlson CG, Axelson O: Malignant lymphomas and occupational exposures. $\mathrm{Br}$ ] Ind Med I 989, 46:5 |6-520.

65. Vianna NJ, Polan A: Lymphomas and Occupational benzene exposure. Lancet 1979, I:1394-1395.

66. Olsson H, Brandt L: Risk of non-Hodgkin's lymphoma among men occupationally exposed to organic solvents. Scand J Work Environ Health 1988, 14:246-25I.

67. Wilcosky T, Checkoway H, Marshall E, Tyroler HA: Cancer mortality and solvent exposures in rubber industry. Am Ind Hyg Association J 1984, 45:809-8II.

68. Spirtas R, Stewart PA, Lee JS, Marano DE, Forbes CD, Grauman DJ, Pettigrew HW, Blair A, Hoover RN, Cohen JL: Retrospective cohort mortality study of workers at an aircraft maintenance facility. I: Epidemiological results. $\mathrm{Br} J$ Ind Med 199I, 48:5I5-530.

69. Brandt L, Kristoffersson U, Olsson H, Mitelman F: Relation between occupational exposure to organic solvents and chromosome aberrations in non-Hodgkin's lymphoma. Eur J Haematol 1989, 42(3):298-302.

70. Wong O, Morgan RW, Bailey WJ, Swencicki RE, Claxton K, Kheifets $\mathrm{L}$ : An epidemiological study of petroleum refinery employees. $\mathrm{Br}$ J Ind Med 1986, 43:6-17.

71. Christie D, Robinson K, Gordon I, Bisby J: A prospective study in the Australian petroleum industry. II Incidence of Cancer. $\mathrm{Br}$ J Ind Med I99I, 48:5II-5I4.

72. Thomas TL, Waxweiler RJ, Moure-Eraso R, Itaya S, Fraumeni J: Mortality patterns among workers in three Texas oil refineries. J Occup Med 1982, 24:|35-|4|.

73. Hoddson JT, Jones RD: Mortality of styrene production, polymerization and processing workers at a site in northwest England. Scand J Work Environ Health 1985, I I:347-352.

74. Li FP, Fraumeni JF, Mantel N, Miller RW: Cancer mortality among chemists. I Natl Cancer Inst 1969, 43: I I59-I I64.

75. Olin R: Leukemia and Hodgkin's disease among Swedish chemistry graduates. Lancet 1976, 2:916.

76. Ott MG, Teta MJ, Greenberg HL: Lymphatic and hematopoietic tissue cancer in a chemical manufacturing environment. Am J Ind Med 1989, 16:631-643

77. Rinsky RA, Ott G, Ward E, Greenberg HL, Halperin W, Leet T: Study of mortality among chemical workers in the Kanawha Vally of West Virginia. Am J Ind Med 1988, 13:429-438.

\section{Publish with Bio Med Central and every} scientist can read your work free of charge

"BioMed Central will be the most significant development for disseminating the results of biomedical research in our lifetime. "

Sir Paul Nurse, Cancer Research UK

Your research papers will be:

- available free of charge to the entire biomedical community

- peer reviewed and published immediately upon acceptance

- cited in PubMed and archived on PubMed Central

- yours - you keep the copyright

Submit your manuscript here:

http://www.biomedcentral.com/info/publishing_adv.asp
BioMedcentral 